\title{
ZAKAT DI MALAYSIA DALAM PERSPEKTIF EKONOMI
}

\author{
Nurhasanah $^{*}$
}

\begin{abstract}
Zakat in Malysia and its' Economical Perspective. Zakâh is the implications of the high level of practice Muslims toward the teachings of Islam in Malaysia. It has been carried out since the pre-colonial, colonial times, post-independence, 1957, 80s, and 90s to the present. Regulatory changes are not necessarily set zakat source in accordance with the economic development and professional management. In zakâh management, government noted that the potential fellowship zakâh increased in accordance with the economic progress of the Muslim community. To foster public confidence in the management of zakâh, government through the Majelis Islam Wilayah Persekutuan (MAIWIP) established the Center levy zakâh (PPZ) in 1991 in order to create a professional zakâh management by implementing corporate systems.
\end{abstract}

Keywords: zakâh, Malaysia, economy, corporate

\begin{abstract}
Abstrak: Zakat di Malaysia dalam Perspektif Ekonomi. Zakat sebagai implikasi tingginya tingkat pengamalan umat Islam terhadap ajaran-ajaran Islam di Malaysia sudah dilaksanakan sejak masa pra penjajahan, masa penjajahan, pasca kemerdekaan 1957, tahun 80-an, dan tahun 90-an hingga saat ini. Perubahan-perubahan regulasi tersebut tidak serta merta mengatur sumber zakat yang sesuai dengan perkembangan ekonomi dan pengelolaan profesional. Khusus di bidang pengelolaan zakat, pemerintah persekutuan memperhatikan bahwa potensi zakat semakin meningkat sesuai dengan kemajuan perekonomian masyarakat Muslim khususnya. Untuk menumbuhkan kepercayaan masyarakat dalam pengelolaan zakat, pemerintah melalui Majelis Agama Islam Wilayah Persekutuan (MAIWIP) mendirikan Pusat Pungutan Zakat (PPZ) pada tahun 1991 dalam rangka menciptakan pengelolaan zakat yang profesional dengan menerapkan sistem corporate.
\end{abstract}

Kata Kunci: zakat, Malaysia, ekonomi, corporate

Naskah diterima: 7 Agustus 2011, direvisi 8 November 2011, disetujui: 17 November 2011.

${ }^{*}$ Fakultas Syariah dan Hukum UIN Syarif Hidayatullah Jakarta. Jl. Ir. H. Juanda 95, Ciputat, Jakarta Selatan. E-mail: nurzan_y@yahoo.co.id 


\section{Pendahuluan}

Malaysia didominasi oleh masyarakat yang memiliki identitas Melayu-Muslim. Sejak masa kemerdekaan dan beberapa dekade setelahnya, Malaysia memperlihatkan rapatnya asosiasi antara keislaman dan kemelayuan. Bahkan, dalam Konstitusi Federal Pasal 160 (b) dinyatakan bahwa yang disebut Melayu adalah mereka yang beragama Islam, berbicara dan berbahasa Melayu dan mengikuti adat Melayu (who professes the Muslim riligion, habitually speak the Malay language and conforms to Malay customs).

Identitas yang diemban oleh Muslim-Melayu berimplikasi terhadap tingginya tingkat pengamalan ajaran-ajaran Islam dalam tata kehidupan. Salah satu pengamalan ajaran Islam yang bernilai dan punya muatan ekonomi adalah zakat. Penggunaan istilah zakat di Malaysia adalah merujuk kepada zakat harta. Sementara fitrah adalah zakat badan yang berbentuk personal dan dilaksanakan di bulan Ramadan. Seksyen 2 Enakmen Pentadbiran Undang-Undang Islam 1991 Pahang (No. 3), misalnya, menafsirkan bahwa zakat adalah sebagian dari hasil penanaman padi dalam satu tahun dan yang lain adalah pendapatan perniagaan, hewan ternak termasuk uang simpanan emas dan perak. Sedangkan fitrah adalah sebagai sesuatu unit takaran beras atau barang yang sama nilai dengannya. Dan mesti dibayar Muslim berdasarkan hukum syarak. ${ }^{1}$

\section{Zakat dalam Lintasan Sejarah di Malaysia}

Sebelum masa penjajahan, zakat di Malaysia dilaksanakan secara tradisional. Kebijakan dan regulasi mengenai zakat masih sangat kurang. Ketika itu, zakat tidak diatur secara sistematis di bawah Kerajaan (Pemerintah). Kebiasaan zakat dilaksanakan dengan cara membayarkannya oleh penduduk kampung kepada guru-guru agama untuk dibagikan kepada pada ashnâf. Dalam hal ini, guruguru agama berkompeten sebagai amil zakat karena mereka dipandang cakap

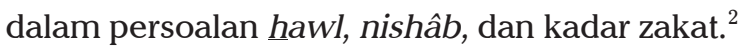

Ketika pada masa penjajahan Inggris, intervensi mereka ke dalam negara Malaysia menimbulkan resistensi yang sengit dari kelompok Melayu terhadap hukum kolonial Inggris. Kondisi ini menyebabkan kekuasaan kolonial merubah metode pemerintahan mereka. Inggris berhasil mengkooptasi kelas penguasa pra-kolonial dengan merekrut mereka sebagai eselon menengah dalam struktur

\footnotetext{
${ }^{1}$ Ahmad Hidayat Buang, ed., Undang-Undang Islam di Malaysia: Prinsip dan Amalan, (Kuala Lumpur: Universitas Malaya, 2007), h. 356.

${ }^{2}$ Aidit bin Ghazali, "Zakat Administration in Malaysia", dalam Mohamed Ariff (ed), Islam and the Economic Development of Southest Asia; the Islamic Voluntary Sector in Southest Asia, (Singapore: ISEAS, 1991), h. 85.
} 
aparatur negara kolonial di mana atasan lansung mereka adalah para pejabat administrator Inggris. ${ }^{3}$ Para Sultan masih punya sedikit pengaruh dalam kebijakan publik, dalam pengertian di mana para pejabat Inggris sangat memperhatikan kedudukan Sultan. Ini memberi kesan bahwa pemerintah kolonial Inggris masih perlu konsultasi dengan Sultan.

Oleh pemerintah kolonial Inggris, kebijakan Negeri-Negeri Melayu dibagi menjadi dua bagian, yaitu kebijakan yang berkaitan dengan Islam dan adat istiadat Melayu diserahkan kepada Council of Relegion and Malay Costom (CRMC) atau Majelis Agama Islam dan Adat Istiadat Melayu (MAIAIM), sementara kebijakan lain seperti perundang-undangan umum, keuangan, dan pendidikan dikeluarkan dan diawasi oleh Inggris. Klasifikasi kebijakan ini memberi kesan seolaholah pemerintah kolonial Inggris menjunjung tinggi status agama dan adat istiadat sebagai kompensasi atas hilangnya kedaulatan para penguasa pribumi. ${ }^{4}$

Dengan berdirinya MAIAIM di setiap Negeri yang diawali oleh Negeri Kelantan, kebijakan zakat dan pengelolaannya diletakkan di bawah kekuasaan lembaga ini. Pada awal pelaksanaannya, muzakkî di setiap kampung membayar zakat kepada imam kampung dan sebagian hasil pungutan zakat diserahkan kepada kerajaan Negeri sebagai sumber pembiayaan negara. ${ }^{5}$

Meskipun Inggris memberikan kebijakan kepada MAIAM dalam persoalan yang berkaitan dengan Islam dan adat istiadat Melayu, namun Inggris tetap memberikan arah kebijakan melalui Majelis Mesyuarat Negeri untuk membuat peraturan tetang zakat. Atas nasihat Inggris, Kelantan membuat peraturan tentang zakat pada tahun 1907 melalui Notis Zakat Kelantan tahun 1907. Selanjutnya, Peraturan tahun 1907 ini berkembang dengan adanya penambahan dan perbaikan menjadi Notis Zakat No. 3 Tahun 1916, dan Notis Kutipan Fitrah No. 11 Tahun 1917. Notis Zakat No. 3 Tahun 1916 ini diganti oleh Enakmen Kutipan Zakat No. 4 Tahun 1927. Dengan Enakmen Majelis Ugama Islam dan Adat Istiadat Melayu Kelantan No. 23 tahun 1938 diperkenalkan dua peraturan baru, yaitu Peraturan Kutipan Fitrah No. 73 Tahun 1938 dan Peraturan Kutipan Zakat No. 74 Tahun 1938 (No.1) ${ }^{6}$.

${ }^{3}$ Jomo K.S, A Question of Class: Capital, the State, and the Uneven Developent in Malaya, (Singapura: New York: Oxford Univerity Press, 1986), h. 245.

${ }^{4} \mathrm{Hua}$ Wu Yin, Class and Communalism in Malaysia: Politics in Dependent Capitalit State, (London: Zed Books,1983), h. 13.

${ }^{5}$ Aidit bin Ghazali, "Zakat Administration in Malaysia", h. 85-86.

${ }^{6}$ Enakmen ini sudah diganti dengan enakmen Enakmen Majelis Agama Islam dan Adat Istiadat Melayu dan Mahkamah Kadi Tahun 1953 (No.1). Enakmen Tahun 1953 ini juga telah diganti oleh Enakmen Majelis Agama Islam dan Adat Istiadat Melayu Kelantan Tahun 1966 (No. 2) dan Enak- 
Keberadaan aturan-aturan yang mengatur tentang zakat di beberapa Negeri Malaysia ini tidak serta merta menjelaskan bagaimana zakat bisa dikelola sehingga menjadi potensi penghimpunan dana yang dapat didistribusikan kepada umat Islam melalui aktivitas-aktivitas yang punya muatan ekonomi. Selain minimnya jumlah muzakkî di Malaysia karena tidak ditopang oleh kehidupan Melayu yang mapan dari segi ekonomi, pemerintah kolonial Inggris sebagai pemegang tampuk kekuasaan terkesan setengah hati dalam hal kebijakan zakat ini. Tidak sedikitpun kebijakan-kebijakan ekonomi Inggris yang pro-Melayu supaya orang Melayu bisa hidup secara layak.

Pasca kemerdekaan 30 Agustus 1957, Melayu di Malaysia berhasil mempertahankan simbol kesultanan sebagai sistem pemerintahannya. Dengan semangat kemelayuan dan nasionalisme, Malaysia kembali dipimpin oleh Tuanku Abdul Rahman. Kondisi perekonomian Malaysia kembali dipulihkan Pemerintah dengan melibatkan orang-orang Melayu di sektor-sektor ekonomi dengan cara memberikan kemudahan-kemudahan akses ekonomi. Namun maksud baik pemerintah belum menunjukkan kemajuan ekonomi yang cukup berarti bagi orang Melayu. Di dunia bisnis contohnya, orang Melayu masih belum mampu bersaing dengan etnis lain seperti Cina.

Meskipun dari segi ekonomi orang Melayu masih tertinggal, namun pengamalan ajaran Islam, seperti zakat yang mempunyai nilai ekonomi, terus berlanjut sesuai dengan kebijakan pemerintah Negeri-Negeri di Malaysia. Pemerintah Negeri mengeluarkan kebijakan-kebijakan dalam bentuk aturan-aturan (Enakmen) yang mengatur tentang zakat.

Hingga akhir tahun 1980-an, penanganan zakat di Malaysia masih jauh dari kesempurnaan. Sejak pemerintah melaksanakan kebijakan islamisasi yang menyeluruh, zakat turut menjadi perhatian utama pemerintah. ${ }^{7}$ setiap Negeri diberikan kepercaaan untuk mengelola zakat sebagaimana yang sudah terlaksana sebelumnya. Aidit bin Ghazali mengatakan bahwa Sejak urusan-urusan yang berhubungan dengan Islam menjadi kekuasaan pemerintah Negeri-Negeri, semua aspek yang berhubungan dengan persoalan zakat juga mejadi tanggung jawab Negeri-Negeri. Yang membuat kebijakan utama dan bentuk administrasinya adalah Majelis Agama masing-masing kecuali Kedah. Kedah mempunyai

men Tahun 1966 ini juga telah diganti oleh Enakmen Majelis Agama Islam dan Adat Istiadat Melayu Kelantan Tahun 1994. Ahmad Hidayat Buang (ed), Mahkamah Syariah di Malaysia: Pencapaian dan Cabaran, (Kuala Lumpur: Universitas Malaya, 2005), h. 81, 103.

${ }^{7}$ Syawal Kaslam, Hasan Bahrom, Amalan Corporate Governance dalam Pengurusan Institusi Zakat di Malaysia, Jurnal Pengurusan JAWHAR, Vol.1, No. 2, 2007, h. 55. 
dewan tersendiri yang disebut dengan Komite Zakat (Jawatankuasa Zakat). Jawatan Zakat ini beroperasi di beberapa kantor dan bertanggung jawab lansung kepada pemerintah Negeri. ${ }^{8}$

Meskipun zakat dikelola oleh Majelis Agama yang ada di 14 Negeri, namun hubungan antara Majelis-majelis tersebut dengan pemerintah Negeri masing-masing tidak sama. Setiap pemerintah Negeri mempunyai Departemen Urusan Agama Islam Negeri (State Department of Islamic Affairs). Jadi fungsi dan peran Departemen dan Majelis itu tergantung kepada dua faktor, yaitu siapa pimpinan Majelis Agamanya dan Apakah Majelis itu mengelola dana sendiri atau didanai oleh Negeri. Pada kenyataannya, Departemen Agama Islam berperan sebagai administrasi sekolah-sekolah agama, aktivitas dakwah, mempersiapkan kursuskursus agama, melaksanakan hukum Islam, pengadministrasian belanja yang berhubungan dengan urusan-urusan Islam, dan pengadministrasian Peradilan Islam. Sedangkan Majelis Agama Negeri fokus kepada administrasi zakat, administrasi dana (fund) Baitulmal dan Wakaf. ${ }^{9}$ Berikut ini adalah tabel yang berhubungan dengan hubungan Departemen Agama Islam dan Majelis Agama Islam pada sembilan Negeri ${ }^{10}$

Tabel 1

\begin{tabular}{lllll}
\hline \multicolumn{1}{c}{ Negeri } & $\begin{array}{c}\text { Majelis Agama } \\
\text { Negeri }\end{array}$ & $\begin{array}{c}\text { Pendanaan } \\
\text { Sendiri }\end{array}$ & $\begin{array}{c}\text { Subsidi } \\
\text { Pemerintah }\end{array}$ & Ketua Majelis Agama \\
\hline Perlis & - & - & - & Ditunjuk Pemerintah Negeri \\
\hline Pulau Pinang & - & - & - & Ketua Departemen Agama \\
\hline Kedah & - & - & & Ketua Departemen Agama \\
\hline Perak & - & - & - & Ketua Departemen Agama \\
\hline Terengganu & - & - & - & Ditunjuk Pemerintah Negeri \\
\hline Pahang & - & - & - & Ketua Menteri \\
\hline Negeri Sembilan & - & - & & State Exco \\
\hline Melaka & - & - & & State exco \\
\hline Johor & - & & &
\end{tabular}

Independensi setiap Negeri sebagai administratif zakat khususnya, berimplikasi pada bentuk pengelolaan zakat. Di Wilayah Persekutuan (pemerintah pusat) dan Perak, misalnya, Majelis Agama Islamnya lebih efekif dalam mengelola

${ }^{8}$ Aidit bin Ghazali, "Zakat Administration in Malaysia”, h. 86-87

${ }^{9}$ A Aidit bin Ghazali, "Zakat Administration in Malaysia", h. 87-88

${ }^{10}$ A Aidit bin Ghazali, "Zakat Administration in Malaysia", h. 89. 
dana zakat. Majelis ini membolehkan dana zakat untuk dikembangkan (diproduktifkan) selain didistribusikan kepada ashnâf dan mereka lebih kreatif untuk menciptakan kesadaran umat Islam dalam membayar zakat. ${ }^{11}$

\section{Regulasi Zakat di Malaysia}

Mengikuti struktur politik yang ada di Malaysia, zakat dikelola oleh masingmasing Negeri dan Negeri mempunyai hak dan kewajiban penuh dalam mengelola zakat. Selain sebagai pengelola, penanggung jawab pengelolaan dan pelaksanaan zakat di Malaysia, Pemerintah melalui perwakilan kerajaan Negeri juga beperan dalam membuat regulasi dalam bentuk undang-undang zakat. Undang-undang tentang zakat dibuat oleh Majelis Perundang-undangan Negeri. Setiap Negeri bebas untuk membuat perundang-undangan zakat. Meskipun mesti berada dalam wilayah undang-undang syariat Islam Negeri. Kebebasan pada kompetensi pembuatan Undang-undang zakat ini, berakibat pada beragamnya beberapa aspek pengelolaan zakat dan cara penegakan hukumnya. Selangor dan Wilayah Persekutuan telah menetapkan hukuman bagi kesalahan tidak membayar zakat dalam Akta atau Undang-undang kesalahan Pidana Syariah. Perkaraperkara yang ada dalam undang-undang boleh ditegakkan hukumannya tapi kalau peraturan zakat itu hanya dalam bentuk tambahan addendum (facia enakmen) yang tidak dimasukkan ke dalam lembaran Negara tidak boleh ditegakkan hukumannya.

Berkaitan dengan undang-undang zakat di Malaysia, Aidit Ghazali mengatakan bahwa ada tiga aspek utama berkaitan dengan undang-undang zakat di Malaysia. Pertama, jenis-jenis zakat yang dikumpulkan oleh lembaga resmi. Kedua, dakwaan pada pelanggaran pelaksanaan zakat. Ketiga, bentuk serta jumlah hukuman dan denda yang boleh dikenakan. Berikut ini adalah undang-undang yang mengatur tentang zakat berdasarkan 14 Negeri di Malaysia: ${ }^{12}$

\footnotetext{
${ }^{11}$ A Aidit bin Ghazali, "Zakat Administration in Malaysia", h. 88.
}

12 Tabel ini di susun penulis, bersumber dari tulisan Ahmad Hidayat Buang, "Dilema Perundangan Zakat di Malaysia: Antara Penguatkuasaan dan Strategi Rujukan/Galakan/Insentif Membayar Zakat, Asmadi Mohamed Naim "Kesahan Pemotongan Caruman KWSP Gaji Pekerja dan Zakat Caruman KWSP Suatu Kajian Semula Menurut Persektif Perundangan Islam”; Aishah Bidin, "Isu Udang-Undang Berkaitan PelaksanaanZakat terhadap Syarikat di Malaysia," dalam Abdul Ghafar Isail dan Hailani Muji Tahir, (ed), Zakat: Pensyariatan Perekonomian dan Perundangan, (Kuala Lumpur: UKM,2006), Cet.I, h. 325-367. 
Tabel 2

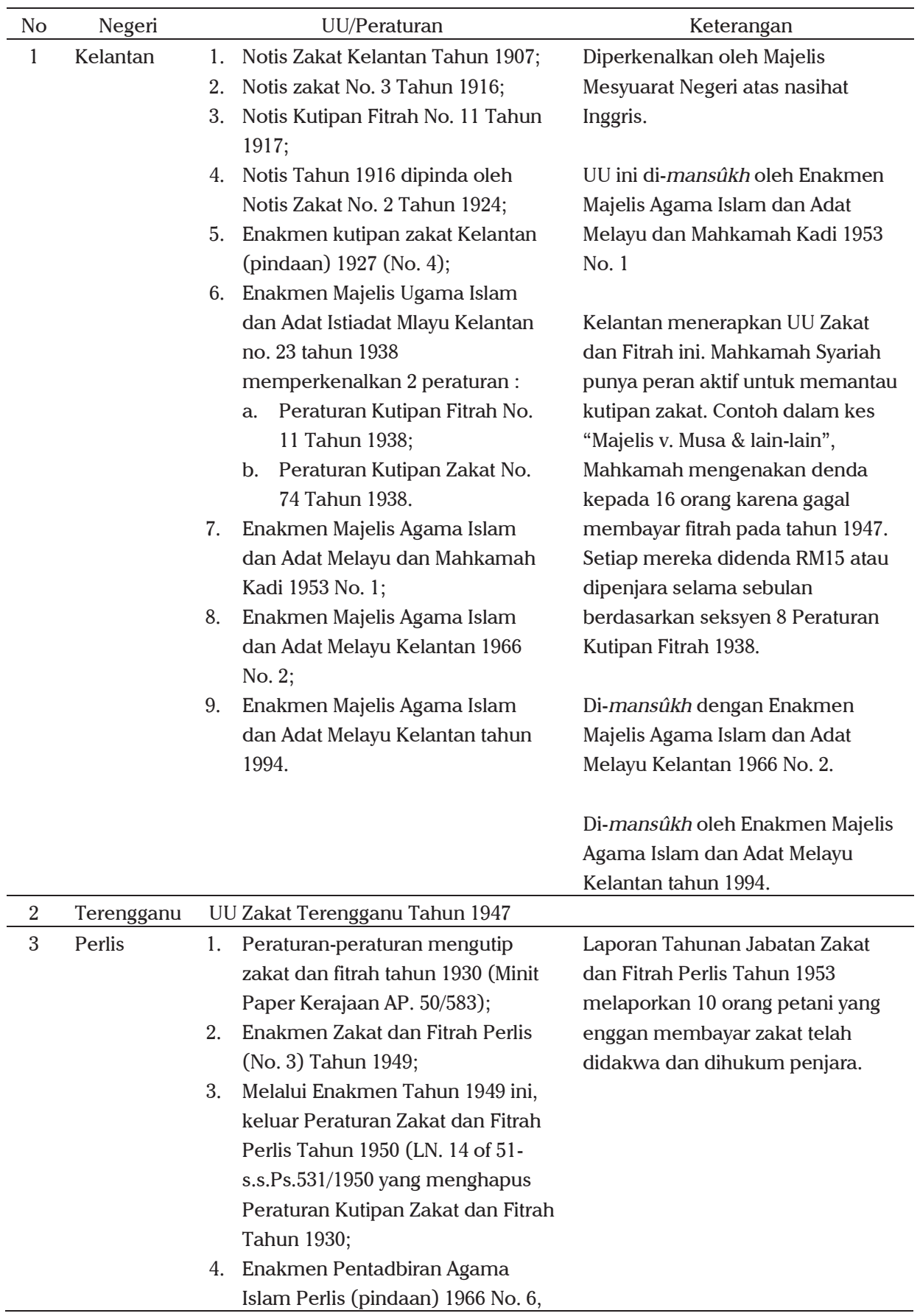




\begin{tabular}{|c|c|c|c|}
\hline & & $\begin{array}{l}\text { membatalkan Enakmen Tahun } \\
\text { 1949, sementara Peraturan tahun } \\
\text { 1950 tidak ada penjelasan masih } \\
\text { berlaku atau sudah dihapuskan; } \\
\text { 5. Peraturan Tabdiran Zakat Padi } \\
\text { pada tahun } 1978 \text { yg ditetapkan } \\
\text { tanggal 10 Januari } 1978 \text { melalui } \\
\text { Titah DYMM Sultan Kelantan } \\
\text { dalam M.A 108/76. }\end{array}$ & \\
\hline 4 & Perak & $\begin{array}{l}\text { Peraturan Zakat dan Fitrah Tahun } 1952 \\
\text { No. } 1222 \text { yang ditetapkan berdasarkan } \\
\text { Enakmen Baitulmal Zakat dan Fitrah } \\
\text { Perak Tahun } 1951 .\end{array}$ & $\begin{array}{l}\text { Tahun } 1953 \text { sebanyak } 52 \text { orang } \\
\text { telah didakwa karena gagal } \\
\text { membayar fitrah. Tahun } 1953 \text {, } \\
\text { tercatat sebanyak } 69.000 \text { orang, } \\
\text { dan } 84.000 \text { orang tahun } 1954 \text { yang } \\
\text { tidak membayar fitrah di seluruh } \\
\text { Negeri Perak. Tahun } 1956 \text { Pejabat } \\
\text { Agama Islam Negeri Perak telah } \\
\text { menemukan sejumlah } 49 \text { orang di } \\
\text { daerah Selama dan } 38 \text { orang di } \\
\text { daerah Setiawan yangg gagal } \\
\text { membayar Fitrah. }\end{array}$ \\
\hline 5 & Johor & $\begin{array}{l}\text { 1. Enakmen Zakat dan Fitrah Johor } \\
\text { Tahun 1957; } \\
\text { 2. UU ini dipindah tahun } 1962 \\
\text { (Peraturan Zakat dan Fitrah Johor } \\
\text { Tahun 1962. }\end{array}$ & $\begin{array}{l}\text { Semua UU dari No. } 1-5 \text { telah di- } \\
\text { mansûkh. }\end{array}$ \\
\hline 6 & Kedah & $\begin{array}{l}\text { 1. Enakmen Zakat Kedah Tahun } 1955 \\
\text { (No. 4); } \\
\text { 2. Pindaan tahun 1962; } \\
\text { 3. (Pindaan) Peraturan zakat Kedah } \\
\text { Tahun } 1982 \text { (K.P.U 11). }\end{array}$ & $\begin{array}{l}\text { Masih berlaku sampai hari ini. } \\
\text { Tahun } 1965 \text { sampai 1966, ada } 36 \\
\text { kasus kesalahan zakat. Hasil } \\
\text { penelitian Mohd Ali Baharom } \\
\text { menjelaskan bahwa sebelum } \\
\text { tahun } 1965 \text { dan setelah tahun } 1966 \\
\text { tidak pernah ada pendakwaan } \\
\text { karena jawatan merinyu zakat yang } \\
\text { bertanggung jawab menerapkan } \\
\text { UU zakat adalah seorang Inspektor } \\
\text { Polis pencen yang berpengalaman. } \\
\text { Keengganan untuk membayar } \\
\text { zakat di Kedah tahun 1965 dan } \\
\text { 1966 itu dibagi 4: } \\
\text { 1. Keengganan memberi } \\
\text { maklumat kepada amil keluasan } \\
\text { tanah yang ditanam padi; } \\
\text { 2. Keengganan membayar zakat; }\end{array}$ \\
\hline
\end{tabular}


3. Kesalahan menerima zakat tanpa tauliahkesalahan; 4. Yang dilakukan oleh amil.

Tahun 1986, tercatat bahwa seorang petani di Kampung Sedakah Kedah pernah di dakwah dan dihukum sebagnyak tiga kali karena tidak membayar zakat padi.

Hasil penelitian Scott tahun 1986 mengatakan bahwa ada kelemahan dalam tindakan hukum bagi petani padi yang enggan membayar zakat. Hak ini disebabkan oleh faktor sosial politik. Faktor sosial adalah amilamil yang ditugaskan memungut zakat tidak mampu menerapkan karena pendapatan mereka tergantung kepada petani-petani tersebut Faktor politik adalah ketegasan amil nantinya akan menyebabkan kehilangan dukungan masyarakat terhadap partai politiknya.

Faktor lain :

1. perubahan mendasar oleh pihak pengelola zakat;

2. kekurangan pakar dan tenaga di bidang pendakwaan;

3. takut kepada tindak balas pembayar zakat yang enggan;

4. kedudukan undang-undang yang tidak kuat;

5. UU zakat tidak bisa memaksa pihak bank untuk mengekspos simpanan (tabungan) Muslim yang dipandang berkewajiban membayar zakat sebagaimana yang terdapat dalam undangundang cukai (pajak) pendapatan. (Menurut Aidit Ghazali tahun 1988); 


\begin{tabular}{|c|c|c|c|}
\hline & & & $\begin{array}{l}\text { menerapkan kutipan zakat } \\
\text { karena beranggapan bahwa } \\
\text { keengganan membayar zakat } \\
\text { kepada Majelis Agama bukan } \\
\text { kesalahan yang serius. Jika } \\
\text { ditindak, pihak yang mangkir } \\
\text { kemungkinan menerima } \\
\text { hukuman yang berat; } \\
\text { 7. Sebagian UU atau peraturan } \\
\text { zakat tersebut tidak diberitakan } \\
\text { penerapannya. }\end{array}$ \\
\hline 7 & Selangor & $\begin{array}{l}\text { 1. Atoran Pentadbiran Ugama Islam } \\
\text { (fitrah dan zakat) } 1953 \text { no. } 1033 \\
\text { yang ditetapkan berdasarkan } \\
\text { Enakmen Pentadbiran Ugama } \\
\text { Islam } 1952 \text { No. } 3 \text {; } \\
\text { 2. (Pindaan) SI. P.U. } 53 \text { tahun 1969; } \\
\text { 3. Peraturan Kutipan dan Pembagian } \\
\text { Zakat Fitrah Selangor (pindaan) } \\
\text { tahun 1973; }\end{array}$ & $\begin{array}{l}\text { Peraturan ini me-mansûkh } \\
\text { peraturan tahun } 1953 \text { dan } 1969\end{array}$ \\
\hline 8 & Melaka & $\begin{array}{l}\text { Peraturan menjalankan Kerja-kerja } \\
\text { Zakat dan fitrah Melaka tahun } 1960 \\
\text { yang ditetapkan berdasarkan } \\
\text { Enakmen Pentadbiran Ugama Islam } \\
\text { Melaka } 1959 \text { No. } 1 .\end{array}$ & $\begin{array}{l}\text { Tidak ada penjelasan apakah } \\
\text { peraturan ini masih berlaku setelah } \\
\text { peraturan Zakat dan Fitrah, Urusan } \\
\text { Wakaf, dan Baitulmal Negeri } \\
\text { Melaka tahun } 1982 .\end{array}$ \\
\hline 9 & Serawak & $\begin{array}{l}\text { (UU kecl) UU Zakat dan Fitrah } \\
\text { Serawak Tahun } 1966 \text { (Swk. L.N. 94) } \\
\text { yang ditetapkan berdasarkan UU } \\
\text { Melayu Serawak (Cap. 51) }\end{array}$ & $\begin{array}{l}\text { UU kecil ini akhirnya diserap ke } \\
\text { dalam Majelis Islam } \\
\text { (incorporation) Ordinance Cao. } \\
105 \text { (Reprinted) 1972). }\end{array}$ \\
\hline 10 & Pahang & $\begin{array}{l}\text { UU Kecil tahun } 1970 \text { yang ditetapkan } \\
\text { berdasarkan Kaedah Zakat dan Fitrah } \\
\text { Pahang } 1970 \text { (Phg mP.U. 18) }\end{array}$ & $\begin{array}{l}\text { Pahang adalah Negeri yang paling } \\
\text { aktif memberikan dakwaan di } \\
\text { mahkamah berhubungan dengan } \\
\text { kutipan zakat dan fitrah. Tahun } \\
1985 \text { ada } 28 \text { kasus, tahun } 1986 \text { ada } \\
13 \text { kasus dan tahun } 1987 \text { ada } 126 \\
\text { kasus. }\end{array}$ \\
\hline 11 & Sabah & $\begin{array}{l}\text { Enakmen Zakat dan Fitrah Sabah } \\
\text { Tahun } 1993 \text { No.6 }\end{array}$ & $\begin{array}{l}\text { Enakmen ini berdasarkan kepada } \\
\text { draf UU zakat yg dibuat oleh } \\
\text { Jawatankuasa Teknikal Hukum } \\
\text { Syarak dan Sivil, Bahagian Hal } \\
\text { Ehwal Islam, Jabatan Perdana } \\
\text { Menteri (Sekarang Jabatan } \\
\text { Kemajuan Islam Malaysia/ JAKIM). } \\
\text { Banyak kesamaan antara draf } \\
\text { Enakmen Zakat dan Fitrah Sabah } \\
\text { tahun } 1993 \text { n0. } 6 \text { dengan draf UU }\end{array}$ \\
\hline
\end{tabular}


JAKIM ini (Draf Akta Zakat Wilayah

Persekutuan).

\begin{tabular}{llll}
\hline 13 & Wilayah & 1. & Kaedah Baitulmal Wilayah \\
& Perekutuan & & Persekutuan (perbelanjaan dan \\
& & penggunaan) 1980 (P.U.(A) 154; \\
& & 2. Kaedah tahun 1988 (P.U. (A) 436); \\
& & 3. $\quad$ Kaedah tahun 1996 (P.U.(A)58). \\
\hline 14 & Negeri & Kaedah Zakat Negeri Sembilan 1998 \\
& Sembilan
\end{tabular}

\section{Sumber Zakat di Malaysia}

Ada empat sumber zakat di Malaysia, yakni: hasil pertanian, zakat perniagaan, zakat gaji pekerja (pendapatan), dan zakat perusahaan. Khusus pada zakat pertanian, mayoritas undang-undang yang berlaku di semua Negeri menjelaskan hanya padi sebagai sumber zakat seperti dalam Enakmen Pentadbiran Undangundang Agama Islam (Fitrah dan Zakat) (pindaan) Tahun 1969 Pasal 9 menjelaskan bahwa zakat pertanian hanya dikenakan kepada padi saja, ${ }^{13}$ tanpa menyebutkan produktivitas tanaman lain seperti karet, kelapa sawit, cokelat, kopi, buah-buahan, dan sayur-sayuran.

Memang berkenaan dengan zakat pertanian, surah al-An'âm [6] ayat 141, surah al-Baqarah [2] ayat 267, dan dalam Hadis Nabi yang diriwayatkan Ibn 'Umar yang menjelaskan bahwa tanaman yang dialiri oleh air hujan, mata air, atau air dari bumi dikenakan zakat 10 persen, sedangkan yang diairi dengan sistem pengairan zakatnya adalah 5 persen, ${ }^{14}$ tidak menjelaskan secara rinci jenis zakat tanaman/pertanian yang dikeluarkan zakatnya, meskipun ada beberapa pendapat ulama dalam hal ini. Pertama, mazhab Mâlikîi ${ }^{15}$ dan Syâfi' $1^{16}$ mensyaratkan bahwa zakat dikenakan kepada makanan pokok suatu tempat, bisa dikeringkan dan tahan disimpan lama. Ada lima makanan pokok yang dimaksud di sini yaitu, padi, gandum, jagung, kurma, dan anggur. Kedua, mazhab Hanbalî ${ }^{17}$ berpendapat bahwa zakat dikenakan kepada semua jenis tanaman makanan dengan syarat bisa ditimbang, disimpan, dikeringkan serta ditanam oleh manusia sendiri. Ini meliputi semua jenis makanan baik makanan pokok maupun tidak

\footnotetext{
${ }^{13}$ Mujaini Tarmin, Zakat Pertanian Sistem dan Pelaksanaannya, (Kuala Lumpur: Dewan Bahasa dan Pustaka, 1990), h. 56.

${ }^{14}$ Diterjemahkan sendiri dari ktab Abû 'Ubayd, Kitâb al-Amwâl, (Bayrût: Dâr al-Fikr, t.th), h. 577.

${ }^{15} \mathrm{Al}$-Dusuki, Hâsyiyah al-Dusuki al-'Ilmiyyah, (Bayrût: Dâr al-Kutub, 1996), Jilid II, h. 30.

${ }^{16}$ Al-Khâtib al-Syarbini, Mughni al-Muhtaj, (Bayrût: Dâr al-Ma'rifah, 1997), Jilid I, h. 565.

${ }^{17}$ Ibn Qudâmah, al-Mughnî, (Riyadh: Dâr al-'Alim, 1997), Jilid 4, h. 55.
} 
dengan syarat yang telah disebutkan. Ketiga, Abû Hanîfah $^{18}$ berpendapat bahwa zakat pertanian diwajibkan kepada semua jenis tanaman makanan, baik makanan pokok ataupun tidak tanpa ada syarat. Argumennya, zakat pertanian ini diwajibkan kepada semua jenis tanaman karena tanaman adalah hasil yang tumbuh dari bumi dan diusahakan petani dengan niat menjalankan usaha pertanian untuk mendapatkan kekayaan. Selain itu, sasaan utama pengeluaran zakat adalah untuk mendistribusikan kekayaan. Oleh karena itu, kalau dibatasi kepada tanaman tertentu, sasaran zakat tidak akan tercapai. Untuk itu Abû Hanîfah mengklasifikasikan tanaman kepada beberapa jenis, yaitu: biji-bijian berupa makanan pokok, makanan bukan makanan pokok seperti ketumbar, tebu, dan lain-lain, sayur-sayuran, buah-buahan, dan tanaman bukan makanan seperti kapas (Q.s. al-An'âm [6]: 141).

Sebagaimana dikatakan oleh Shirlie Gordon, UU dan peraturan tentang zakat padi meskipun bermanfaat untuk orang Islam, namun pada hakikatnya dapat menekan kelompok miskin. Karena mewajibkan pembayaran zakat padi kepada mayoritas petani miskin. Kebanyakan petani penyewa tanah dari tuan tanah. UU dan peraturan mewajibkan petaninya bukan tuan tanah yang bayar zakat. Petani terbebani untuk membayar sewa dan zakat dari hasil yang sama.

Zakat yang bersumber dari gaji pekerja (pendapatan) diwajibkan pemerintah pusat dan berlaku untuk semua Negeri, melalui persetujuan pekerja yang dinyatakan dalam kontrak kerja. Pemerintah mewajibkan pekerja dan majikan untuk membayar. Sebagaimana pada zakat gaji (pendapatan), zakat perniagaan juga dianjurkan pemerintah dengan ketentuan pemerintah memberikan potongan pajak bagi muzakkî pendapatan dan perniagaan berdasarkan Akta Cukai Pendapatan Tahun 1967. Sedangkan zakat perusahaan di Malaysia belum populer dilaksanakan. Ini disebabkan oleh tiga faktor pertama, kelemahan dari segi undang-undang (lacunae) yang mengatur. Kedua struktur perusahaan yang berbeda dan kompleks dan ketiga, persoalan pembagian kekuasaan pemerintah pusat (kerajaan persekutuan) dan pemerintah Negeri (kerajaan Negeri).

Di tingkat Pemerintahan Pusat UU Sipil memulai Seksyen 2 Akta Tafsiran 1950 menggunakan istilah orang "persons" pada wajib pajak sedangkan Akta Cukai Pendapatan 1967 mnggunakan istilah "individu" bagi wajib pajak. Kedua istilah ini mempunyai arti berbeda secara hukum. Istilah "orang" berarti badan perseorangan, perusahan dan lembaga. Sedangkan "individu" berarti badan perseorangan. Jika Akta tahun 1950 memberikan porsi yang sama dengan pengerian

${ }^{18}$ Al-Kasani, Bada't al-Sna't, (Lubnan: Dâr Ihyâ' al-Turâth al-‘Arabî, 1998), Jilid II, h. 178-179. 
orang perorangan (individu) dan perusahaan, maka Akta Cukai 1967 jelas membedakan antara individu dan perusahaan.

Pelaksanaan zakat menjadi bidang kekuasaan pemerintah Negeri yang termaktub dalam enakmen setiap Negeri sedangkan perusahaan diatur oleh undang-undang sipil yang menjadi kekuasaan pemerintah pusat. Adapun UU tentang perusahaan yang pernah berlaku di Malaysia adalah: Akta Syarikat 1965, Akta Pendaftaran Syarikat Syarikat 1965, Akta Pelaburan Kerajaan 1983, Akta Perindustrian Sekuriti 1983, Akta Perbankan, dan Institusi Kewangan 1989, Akta Suruhanjaya Sekuriti 1993, dan Akta Suruhanjaya Syarikat 2001. Selain itu masih ada kaedah lain yang dipakai seperti Kod. Amalan Pengarah dan Kod. Tadbiurus Syarikat 1999 sebagai panduan perusahaan.

\section{Zakat di Era Modern}

Dari awal sejarah pelaksanaan zakat di Malaysia, pengelolaan zakat belum dikelola secara profesional, maka potensi zakat di Malaysia belum terjaring secara signifikan. Dengan kemajuan ekonomi di Malaysia, ekonomi orang Melayu pun mulai mengalami kemajuan. Potensi zakat yang cukup baik untuk mengembangkan kemajuan ekonomi, ${ }^{19}$ dapat dijadikan pemerintah untuk memperbaiki sistem pengelolaan zakat. Zakat dikelola secara profesional dengan memakai pola corporate governance. Konsep corporate governance menekankan kepada pentingnya peranan dan tanggung jawab pengurus dalam mengelola zakat dan juga untuk menumbuhkan integritas dan keyakinan masyarakat. Peran dan tanggung jawab pengurus adalah melaksanapengelolaan zakat secara ikhlas, bertanggung jawab, amanah, dan profesional supaya tujuan organisasi dapat tercapai dan kepentingan masyarakat terhadap zakat dapat terpenuhi. ${ }^{20}$

Berikut ini ada dua lembaga zakat di Malaysia yang mengamalkan pola corporate governance ini. Pertama, Pusat Pungutan Zakat (PPZ). PPZ di Wilayah Persekutuan berdiri 27 Desember 1990 sebagai lanjutan dari ide gagasan pembentukannya sejak Mei 1989. Munculnya gagasan pembentukan PPZ dimotori oleh adanya keresahan masyarakat Muslim tentang pengelolaan zakat yang tidak berkembang. Kelemahan institusi yang ada disebabkan oleh buruknya mena-

${ }^{19}$ Tahun 2001, total perolehan zakat di Malaysia adalah RM 320.348.659. Dana ini berasal dari zakat pendapatan (profesi), zakat tabungan, zakat harta, qadhâ zakat, zakat fitrah, serta sedikit dari infak sedekah. Khusus untuk zakat profesi, PPZ membidik para muzakkî yang berpenghasilan minimal RM 5.000 per bulan.

${ }^{20}$ Shawal Kaslam, Hasan Bahrom, "Amalan Corporate Governance dalamPengurusan Institusi Zakat di Malaysia”, dalam Jurnal Pengurusan Jawhar, Vol. 1, No. 2, h. 53. 
jemen pengelolaan zakat sehingga kinerja institusi pengelola zakat membuat muzakkî mengalami kesulitan untuk membayar zakat.

Berdasarkan realita ini, pemerintah mengontak konsultan asing Coopers and Lybrand untuk mengkaji potensi zakat. Konsultan ini ditugaskan untuk mendesain struktur dan sistem organisasi termasuk merancang model promosi dan kiat-kiat marketing guna meningkatkan pendapatan zakat. Desain konsultan berorientasi pada usulan PPZ menjadi sebuah perusahaan murni (korporat) dengan penekanan pada cara kerja yang profesional.

PPZ yang menginduk pada Majelis Agama Islam Wilayah Persekutuan (MAIWP) di Kuala Lumpur pada awal berdirinya sampai 2003 dipimpin Moh. Dohan bin Abdul Latiff (CEO). Moh. Dohan merekrut SDM PPZ dari latar belakang pendidikan yang beragam dan mempersiapkan karakter penghimpunan zakat berbasis teknologi komputer. PPZ resmi beroperasi tanggal Maret 1991 dan diresmikan oleh PM Mahathir Mohammad. Adapun pengumpulan zakat di Wilayah Persekutuan periode 1991-2003 adalah:

Table 3

\begin{tabular}{ccc}
\hline Tahun & Jumlah Zakat (RM) & Jumlah Kenaikan (RM) \\
\hline 1991 & 14,6 juta & - \\
\hline 1992 & 21,2 juta & 6,6 juta \\
\hline 1993 & 26,8 juta & 5,6 juta \\
\hline 1994 & 34,4 juta & 7,6 juta \\
\hline 1995 & 33,6 juta & $-0,8$ juta \\
\hline 1996 & 42,9 juta & 9,3 juta \\
\hline 1997 & 52,8 juta & 9,9 juta \\
\hline 1998 & 45,7 juta & $-7,1$ juta \\
\hline 1999 & $36,0 j u t a$ & $-9,7$ juta \\
\hline 2000 & 58,9 juta & 22,9 juta \\
\hline 2001 & 72,9 juta & 14,0 juta \\
\hline 2002 & 84,5 juta & 11,6 juta \\
\hline 2003 & 96,4 juta & 11,9 juta \\
\hline
\end{tabular}

Sumber: Laporan Zakat 2003 PPZ MAIWP

Tahun 2001, perolehan zakat oleh PPZ sekitar RM 72,9 dikutip dari 40 ribu muzakkîyang berdomisili di Kuala Lumpur. 1/8 dari perolehan zakat ini yaitu RM. 8 juta diambil untuk biaya operasional dan gaji pegawai dan RM 64 juta diserahkan ke Baitulmal. Tahun 2002, perolehan zakat oleh PPZ sekitar RM 84,5 juta. 
RM 4 juta berasal dari zakat perniagaan tabungan haji. Tahun 2002, tabungan haji mengeluarkan zakat RM 18 juta yang didistribusikan ke 14 Negeri bagian.

Kedua, Pusat Zakat Selangor (PZS). PZS didirikan tanggal 15 Februari 1994 sekaligus terdaftarnya Syarikat Mais Zakat Sdn. Bhd sebagai anak perusahaan sepenuhnya milik Majelis Agama Islam Selangor (MAIS) dengan modal sebanyak RM 500.000.- Lembaga ini mulai beroperasi sepenuhnya pada bulan Oktober 1995. Adapun pengumpulan zakat di Selangor periode 1991-2003 adalah:

Table 4

\begin{tabular}{ccc}
\hline Tahun & Jumlah Zakat (RM) & Jumlah Kenaikan (RM) \\
\hline 1991 & 7,5 juta & 2,5 juta \\
\hline 1992 & 10,0 juta & 0,3 juta \\
\hline 1993 & 10,3 juta & 3,5 juta \\
\hline 1994 & 13,8 juta & $-0,8$ juta \\
\hline 1995 & 13,2 juta & 14,7 juta \\
\hline 1996 & 27,9 juta & 14,7 juta \\
\hline 1997 & 37,2 juta & 9,3 juta \\
\hline 1998 & 37,3 juta & 0,1 juta \\
\hline 1999 & 37,7 juta & 0,4 juta \\
\hline 2000 & 46,2 juta & 8,5 juta \\
\hline 2001 & 61,4 juta & 15,2 juta \\
\hline 2002 & 78,7 juta & 17,3 juta \\
\hline 2003 & 86,2 juta & 7,5 juta \\
\hline
\end{tabular}

Sumber: Laporan Zakat 2003, PPZ MAWIP

Selain PPZ dan PZH, ada lima lembaga zakat swasta di Malaysia, yaitu: Lembaga Zakat Selangor (LZS), Pusat Urus Zakat (PUZ) di Pulau Pinang, Pusat Kutipan Zakat (PKZ) di Pahang, Pusat Zakat Negeri Sembilan (PZNS), dan Pusat Zakat Melaka (PZM). Di antara tujuh lembaga itu, hanya dua lembaga yang diberi tanggung jawab untuk mengelolah zakat sepenuhnya seperti memungut zakat dan mendistribusikannya yaitu Lembaga Zakat Selangor (LZS) dan Pusat Urus Zakat (PUZ) di Pulau pinang sementara yang lain hanya bertugas memungut zakat saja sementara yang mendistribusikannya adalah Baitulmal (unit zakat) di bawah Majelis Agama Islam Negeri maing-masing.

Di samping tujuh lembaga zakat swasta di Malaysia, ada tujuh lembaga zakat pemerintah yang dikelola langsung oleh Majelis Agama Islam Negeri sebagai agensi kerajaan Negeri. Adapun tujuh Negeri tersebut adalah: (1) Majelis Agama Islam Negeri Johor; (2) Majelis Agama Islam dan Adat Melayu Perak; (3) 
Jabatan Zakat Negeri Kedah; (4) Majelis Agama Islam dan Adat Istiadat Melayu Perlis; (5) Majelis Agama Islam dan Adat Melayu Kelantan; (5) Majelis Agama Islam dan Adat Melayu Terengganu; (6) Tabung Baitulmal Serawak.

Di bawah ini ditampilkan tabel yang menggambarkan penghimpunan zakat dari 14 Negeri bagian Malaysia pada tahun 1991, 1997, 1999, dan 2001. Tahun ini menggambarkan tiga hal penting yaitu: tahun 1991 merupakan tonggak kelahiran PPZ, tahun 1997 dan 1999 menjelaskan krisis moneter yang mempengaruhi naik turunnya nominal penghimpunan zakat dan tahun 2001 menggambarkan perolehan zakat terkini sebagai akhir periodisasi pemerintahan Mahathir.

Table 5

\begin{tabular}{llrrrr}
\hline NO & \multicolumn{1}{c}{ NEGERI } & $1991(\mathrm{RM})$ & $1997(\mathrm{RM})$ & $1999(\mathrm{RM})$ & $20001(\mathrm{RM})$ \\
\hline 1 & $\begin{array}{l}\text { Wilayah } \\
\text { Persekutuan }\end{array}$ & 14.639 .933 & 52.850 .927 & 36.019 .248 & 72.886 .035 \\
\hline 2 & Selangor & 7.505 .522 & 37.213 .288 & 37.760 .000 & 31.432 .750 \\
\hline 3 & Johor & 6.567 .911 & 22.612 .834 & 28.591 .949 & 31.432 .921 \\
\hline 4 & Terengganu & $4,584.147$ & 12.883 .924 & 12.499 .444 & 28.247 .343 \\
\hline 5 & Perak & 6.705 .526 & 15.629 .554 & 15.695 .046 & 20.468 .412 \\
\hline 6 & Pulau Pinang & 2.623 .824 & 9.716 .224 & 10.388 .466 & 17.550 .949 \\
\hline 7 & Pahang & 2.805 .483 & 9.225 .865 & 9.375 .239 & 16.625 .473 \\
\hline 8 & Kelantan & 3.332 .410 & 11.171 .432 & 9.533 .087 & 16.582 .718 \\
\hline 9 & Negeri Sembilan & 2.784 .985 & 7.470 .136 & 8.763 .046 & 13.230 .123 \\
\hline 10 & Kedah & 2.757 .326 & 6.409 .012 & 8.399 .694 & 12.487 .629 \\
\hline 11 & Melaka & 4.381 .836 & 8.556 .377 & 7.656 .886 & 12.034 .520 \\
\hline 12 & Serawak & 1.507 .696 & 3.907 .769 & 4.611 .670 & 8.318 .162 \\
\hline 13 & Sabah & 910.571 & 2.604 .679 & 3.743 .029 & 5.331 .114 \\
\hline 14 & Perlis & 1.541 .811 & 3.203 .206 & 2.469 .199 & 3.720 .504 \\
\hline & Jumlah & 61.107 .168 & 203.455 .228 & 195.506 .008 & 320.348 .659 \\
\hline
\end{tabular}

\section{Zakat dan Kemiskinan}

Mengenai penyaluran dana zakat, hasil wawancara penulis dengan salah seorang pengurus PPZ mengatakan bahwa zakat di Malaysia disalurkan untuk dana-dana sosial dalam rangka memperkecil tingkat kemiskinan ditengah masyarakat Muslim-Melayu. Zakat digunakan untuk membantu para ashnâf yang membutuhkan bantuan. Meskipun ada dana zakat disalurkan untuk perniagaan, tujuannya adalah membantu pedagang kecil dalam berusaha. Bentuk akad yang dipakai adalah qardh al-hasan.

Meskipun semua dana zakat ini digunakan untuk program pengentasan kemiskinan masyarakat Muslim, akan jauh lebih kecil dari total dana yang dike- 
luarkan pemerintan untuk program pengentasan kemiskinan ini. ${ }^{21}$ Ini artinya, pemerintah Malaysia lebih berkompeten dalam upaya mengentaskan kemiskinan dalam upaya menciptakan sosio-ekonomi. Zakat adalah salah satu program pemerintah dalam upaya pengentasan kemiskinan. Oleh karena itu pemerintah di era Mahathir tidak mau mengatakan bahwa zakat adalah satu-satunya upaya pengentasan kemiskinan, meskipun pemerintah telah merestui operasional PPZ tahun 1991 sebagai salah satu dari bentuk BUMN.

Dalam konteks kemiskinan di Malaysia, Mahathir mengatakan bahwa sebelum mardeka, Malaysia termasuk dalam kategori negara miskin. Dalam waktu 46 tahun Malaysia telah menjadi negara industri dan akan berlanjut kepada industri jasa berbasis teknologi informasi. Kemiskinan telah menurun dari 52,4\% pada tahun 1970 menjadi 21\% pada tahun 1983 dan hanya 5,1\% pada 2002. 92\% rumah-rumah di seluruh pedesaan sudah memiliki listrik, sementara 86\% menerima air bersih pada tahun 2003. Demikian halnya dengan pendapatan per kapita meningkat hampir tiga kali lipat dari RM 1.098 per bulan di tahun 1983 menjadi RM 3.011 di tahun 2002. Walaupun target 30\% kekayaan negara belum dicapai bumiputra tapi disparitas ekonomi antara kelompok-kelompok etnis jelas menurun. Pada tahun 1970, kaum bumiputra hanya memiliki 2,4\% kekayaan negara. Tapi pada tahun 2002 sudah mencapai 18,7\%. Kalau dalam nilai agregat berarti dari RM 126 juta pada tahun 1970 menjadi RM 73.162 juta pada tahun $2002 .^{22}$

Dapat dipahami bahwa pelaksanaan zakat di Malaysia bukanlah satu-satunya upaya untuk mengentaskan kemiskinan. Selain lembaga-lembaga zakat yang ada di tingkat persekutuan dan Negeri, ada lembaga-lembaga pemerintah dan non-pemerintah berbentuk Lembaga Swadaya Masyarakat seperti Amanat Ikhtiar Malaysia (AIM), namun kebanyakan lembaga-lembaga tidak terlepas dari kontrol pemerintah. Adapun lembaga pemerintah yang bergerak untuk mengentaskan kemiskinan adalah Kementerian Perpaduan Negara dan Pembangunan Masyarakat (Jabatan Kebajikan Masyarakat) dan Kementerian Pembangunan Luar Bandar (KPLB) yang mempunyai sembilan agensi yaitu: Lembaga Penyatuan dan Pemulihan Tanah Persekutuan (FELCRA), Institut Kemajuan Desa (INFRA),

\footnotetext{
${ }^{21}$ Abang Mohamad Shibli bin Abang Mohamad Nailie, "Peranan Zakat dalam Pembangunan Umat", dalam Nik Mustapha Nik Hassan, Ekonomi Islam dan Pelaksanaannya di Malaysia, (Kuala Lumpur: IKIM2002), Cet. I, h. 240-241.

${ }^{22}$ Wawancara Liem Siok Lan dengan Mahathir tentang Malaysia Incorporated 2020 dalam buku Menembus Batas (Beyond Boundaries), (Jakarta: Yayasan Obor Indonesia, 2008), h. 121, 122 dan 124 .
} 
Lembaga Kemajuan Johor Tenggara (KEJORA), Lembaga Kemajuan Wilayah Kedah (KEDA), Bahagian Kemanjuan Masyarakat (KEMAS), Lembaga Kemajuan Kelantan Selatan (KETENGAH), Lembaga Kemajuan Wilayah Pulau Pinang (PERDA) dan pihak Berkuasa Kemajuan Perkebunan Kecil Perusahaan Getah (RISDA).

Lembaga-lembaga ini mengembangkan aktivitas dan programnya dalam mendampingi kalangan miskin. Seperti penciptaan lapangan kerja, pendidikan, dan pelatihan. Bentuk subsidi langsung pemerintah yang tidak mendidik secara bertahap dihilangkan karena ini dapat menurunkan rasa percaya diri rakyat dan kurang menghargai daya juang bangsa Malaysia. ${ }^{23}$

Di Malaysia, selain kuantitas kelompok miskin relatif kecil, tingkat kemiskinan pun dari segi penghasilan cukup sejahtera bila dibandingkan dengan Indonesia, misalnya, tahun 1998, mustahiq yang berhak menerima zakat adalah bumiputera miskin yang berpenghasilan di bawah RM 700. Sedangkan pada tahun 2003, mustahiq adalah bumiputera miskin yang berpenghasilan di bawah RM 1.200 .

\section{Penutup}

Pemerintah Malaysia punya peran besar dalam pengaplikasian zakat dengan mengeluarkan berbagai kebijakan melalui Enakmen di 14 Negeri. Sejak era Melayu tradisional sampai tahun 90-an, kebijakan dan pengelolaan zakat menjadi kekuasaan Majelis Agama Islam masing-masing Negeri.

Undang-undang zakat yang telah ada, belum secara utuh menerapkan zakat. Karena diperhatikan, Enakmen-enakmen tersebut belum mengatur semua sumber zakat yang telah disebutkan seperti zakat pertanian, zakat pendapatan, zakat perniagaan, dan zakat perusahaan. Tidak semua sumber zakat ini dikelola sepenuhnya oleh Negeri, seperti zakat perusahaan yang belum populer karena ini menjadi otoritas pemerintah pusat.

Seiring dengan kemajuan ekonomi umat Islam, pemerintah melihat bahwa potensi zakat semakin meningkat. Oleh karena itu, pada tahun 90-an, pemerintah mulai menggalakkan sistem pengelolaan zakat secara profesional yaitu dengan sistem corporate. Pengeloalaan ini dimulai pertama kali oleh PPZ yang diresmikan Mahathir Mohamad pada tahun 1991.

Zakat yang mempunyai nilai ekonomi, turut mendukung program pemerintah dalam upaya pengentasan kemiskinan. Meskipun potensi zakat semakin

\footnotetext{
${ }^{23}$ Wawancara Liem Siok Lan dengan Mahathir. h. 137.
} 
berkembang seiring dengan kemajuan ekonomi orang Melayu khususnya dan Malaysia umumnya, zakat bukan satu-satunya upaya pemerintah untuk mengentaskan kemiskinan. Upaya lain untuk mengentaskan kemiskinan ini diprogram pemerintah secara khusus dengan adanya kementerian Perpaduan Negara dan Pembangunan Masyarakat (Jabatan Kebajikan Masyarakat) dan Kementerian Pembangunan Luar Bandar (KPLB) yang khusus membidanginya. []

\section{Pustaka Acuan}

Al-Qur'ân al-Karîm

Abû 'Ubayd, Kitâb al-Amwâl, Bayrût: Dâr al-Fikr, t.th.

Bidin, Aishah, "Isu Udang-Undang Berkaitan Pelaksanaan Zakat Terhadap Syarikat di Malaysia", dalam Abdul Ghafar Isail dan Hailani Muji Tahir (ed.), Zakat: Pensyariatan Perekonomian dan Perundangan, Kuala Lumpur: UKM, 2006.

Bin Ghazali, Aidit, "Zakat Administration in Malaysia", dalam Mohamed Ariff (ed.), Islam and the Economic Development of Southest Asia; the Islamic Voluntary Sector in Southest Asia, Singapore: ISEAS, 1991.

Buang, Ahmad Hidayat (ed.), Mahkamah Syariah di Malaysia: Pencapaian dan Cabaran, Kuala Lumpur: Universitas Malaya, 2005.

-------------, Undang-Undang Islam di Malaysia: Prinsip dan amalan, Kuala Lumpur: Universitas Malaya, 2007.

Dusuki, al-, Hasyiyah al-Dusukî al-'Ilmiyyah, Bayrût: Dâr al-Kutb, 1996.

Hua Wu Yin, Class and Communalism in Malaysia: Politics in Dependent Capitalit State, London: Zed Books, 1983.

Ibn Qudâmah, al-Mughnî, Riyâdh: Dâr al-'Alim, 1997.

Jomo K.S, A Question of Class: Capital, the State, and the Uneven Developent in Malaya, Singapura: New York: Oxford Univerity Press, 1986.

Kasani, al-, Bada't al-Sna't, Lubnan: Dâr Ihyâ' al-Turâts al-'Arabî, 1998.

Kaslam, Syawal \& Bahrom, Hasan, "Amalan Corporate Governance dalam Pengurusan Institusi Zakat di Malaysia", Jurnal Pengurusan JAWHAR, Vol. 1, No. 2, 2007.

Nailie, Abang Mohamad Shibli bin Abang Mohamad, "Peranan Zakat dalam Pembangunan Umat", dalam Nik Mustapha Nik Hassan, Ekonomi Islam dan Pelaksanaannya di Malaysia, Kuala Lumpur: IKIM, 2002.

Syabini, al-, al-Khatib, Mughnî al-Muhtâj, Bayrût: Dâr al-Ma'rifah, 1997.

Tarmin, Mujaini, Zakat Pertanian Sistem dan Pelaksanaannya, (Kuala Lumpur: Dewan Bahasa dan Pustaka, 1990. 
Wawancara Liem Siok Lan dengan Mahathir tentang Malaysia Incorporated 2020 dalam buku Menembus Batas (Beyond Boundaries), Jakarta: Yayasan Obor Indonesia, 2008. 